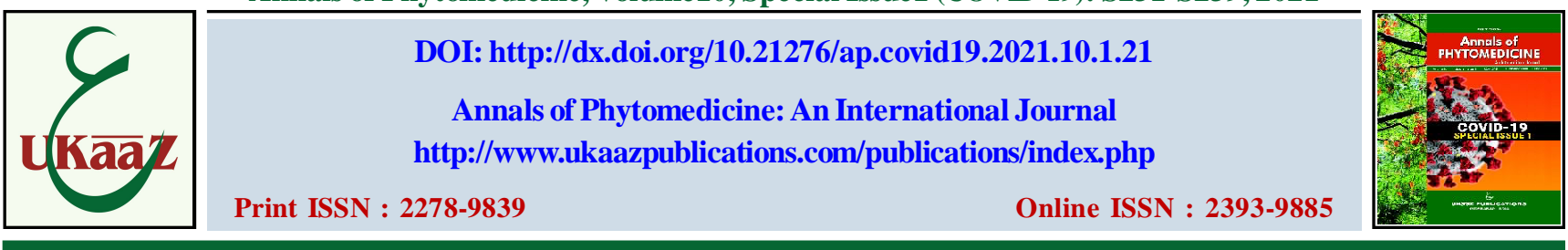

\title{
Role of underground stems as immunomodulators and may assist in the management and treatment of COVID-19
}

\author{
Mohammed Abdul Rasheed Naikodi` and Aaisha Ansari \\ Drug Standardization Research Unit and P.G., Department of Pharmacology, National Research Institute of Unani Medicine for Skin \\ Disorders, A.G. Colony Road, Erragadda, Hyderabad-500038, Telangana State, India
}

\begin{tabular}{|c|c|}
\hline Article Info & Abstract \\
\hline $\begin{array}{l}\text { Article history } \\
\text { Received } 10 \text { April } 2021 \\
\text { Revised } 28 \text { May } 2021 \\
\text { Accepted } 29 \text { May } 2021 \\
\text { Published Online } 30 \text { June } 2021\end{array}$ & $\begin{array}{l}\text { Plants have always been a great source for human being by unveiling invaluable therapeutic activities due } \\
\text { to the presence of various secondary metabolites and other chemicals present in them. The various parts } \\
\text { of the plant are beneficial in offering pharmacological and other biological properties. The utility of } \\
\text { these plants in - particular underground stems are proved to possess beneficial immunomodulatory effects } \\
\text { and on altering the immune system by diverse mechanisms. In present scenario, COVID-19 has gone into }\end{array}$ \\
\hline $\begin{array}{l}\text { Keywords } \\
\text { Underground stem } \\
\text { Immunomodulators } \\
\text { COVID-19 } \\
\text { Medicinal plants }\end{array}$ & $\begin{array}{l}\text { ability of the coronavirus to get acclimatize at all conditions all over the globe. The unabated transmission } \\
\text { of this deadly coronavirus is due to lacks of drugs to fight against this outbreak. But, attempts were made } \\
\text { to formulate the vaccines and few countries have developed the vaccines mainly Russia, India and other } \\
\text { countries. Through, vaccines and other modalities may help scientific communities to bring out a solution } \\
\text { and are continuously striving to unravel the pharmacologically active compounds in all directions that } \\
\text { might prove a new insight for curbing viral infections and pandemics. Hence, the COVID-19 scenario } \\
\text { highlights an essential need for effective therapeutics against SARS-CoV-2. The present review discusses } \\
\text { the role of underground stems as immunomodulators and vital concepts related to COVID-19 which tends } \\
\text { to boost the immunity through immunomodulators from medicinal plants. }\end{array}$ \\
\hline
\end{tabular}

\section{Introduction}

In this paper, an attempt has been made to explore the role of certain underground stems as immunomodulators which may help to suppress the symptoms in the management of COVID-19. The coronavirus disease has been the sudden outburst and WHO on $11^{\text {th }}$ March 2019 declared COVID-19 as a Pandemic COVID-19 is caused by virulent severe acute respiratory syndrome coronavirus-2 (SarsCov-2) virus. SARS-CoV-2, provisionally called as 2019-novel coronavirus, an enveloped positive sense single stranded RNA virus which belongs to subfamily-Orthocoronavirinae, and familyCoronaviridae (Huang et al., 2020; Gorbalenya et al., 2020). Its morphology is like crown shaped over the surface (Figure 1) and broadly distributed among different mammalian species including the human being. The name resembles coronavirus- 2 due to $70 \%$ resemblance to SARS coronavirus.

The host cell, namely; ACE2 in humans got encapsulated by SARs coronavirus- 2 with the spikes proteins projected out. The ACE2 enzyme bound to cell membrane of the tissues present in the lungs, artery, kidney and intestine. WHO declared COVID-19 as a six public health emergencies of the international concern. In history, few more pandemic had occurred where herbs have used as a natural

Corresponding author: Dr. Mohammed Abdul Rasheed Naikodi
Scientist, Drug Standardization Research Unit and P.G., Department
of Pharmacology, National Research Institute of Unani Medicine for
Skin Disorders, A.G. Colony Road, Erragadda, Hyderabad-500038,
Telangana State, India
E-mail: rasheed.crium @gmail.com
Tel.: +91-9959840785

Copyright (c) 2021 Ukaaz Publications. All rights reserved.

Email: ukaaz@yahoo.com; Website: www.ukaazpublications.com treatments for various illness, including viral infections. The plants contain several chemical compounds which are having potency to fight against viruses and other illness caused within the body. Natural antimicrobials are extracted and became popular for use as alternative antivirals. Most antivirals are considered relatively harmless to the host, and therefore can be used to treat infections.

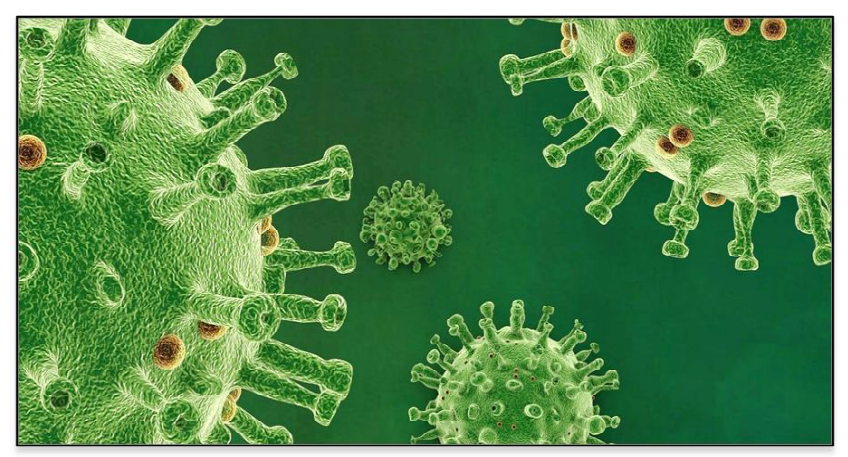

Figure 1: The predictive morphology of coronavirus.

\section{Immune system stimulation}

Medicinal plants constitute effective source of natural products, consumed as phytomedicines and the products obtained from medicinal plants have been playing significant role in drug discovery efforts for the treatment of various diseases. Phytochemicals present in the medicinal plants instead of attacking viruses directly they fight viruses involves encouraging the body immune system to attack them. Some antivirals stimulate the immune system to attack a specific or wide range of pathogens. 
Immunity defined as ability of body to neutralize and eliminate the pathogenic micro-organisms and their toxic products, thus protecting the individual. Autoimmune disease arises when body mounts as immune response against itself due to failure of distinguishing self tissues and cells from foreign antigens. Such diseases are rheumatoid arthritis, systemic lupus erythematous multiple sclerosis and diabetes (type 1).

\section{COVID-19 and traditional medicine}

Globally, there are many healthcare systems recognized such as Herbal medicine, Oriental medicine, Chinese medicine, Korean medicine, etc. The novel COVID-19 is get effected to human by virus, i.e., RNA virus (Coronaviriade family) susceptible to all age people to make them severely ill with various symptoms. The symptoms are mainly similar to that of influenza such as cough, sore throat, fever, pain, chills, shortness of breath, loss of taste and smell. Medicinal plants can play a major role as potential healing agents that can help to curb the symptoms and act against the virus by boosting the immunity, enhancing the power by posing as virucidal action and to supress the mortality rate.

There are so many commercially available antiviral medicines which may serve as potent against the virus such as interferon- $\alpha$, lopinavir/ ritonavir, ribavirin, etc. (Dong et al., 2020). Over all, the immunity plays an important role to fight against the coronavirus, unhealthy surrounding, microbes, bacteria, fungus and other virus, etc. Several modern medicines are available over the counter which can help to improve the immunity and acts against the virus but they are costly.

The potential medicinal plants can produce antiviral and immunestimulant drugs to treat or act against the coronavirus. Such as Withania somnifera, Rubia cordifolia, Curcuma longa, Azadiracta indica, etc. (Srivastava et al., 2020). Traditional medicine has a rich literature regarding infection invasion, source and cause of disease, measures to cure for the epidemics, pandemics for example cataract influenza, etc. (Khan and Al-Balushi, 2021). Combination of potent medicinal plant drugs can be used in controlling the symptoms of COVID-19. These combinations which may produce effects on boosting immunity, improve vital organ or tissues, muscle relaxant, prevent respiratory stress, congestion, breathless ness, prevent pneumonia and other associate condition.

In Unani System of medicine, there are potential single drugs like amla, zanjabeel, halelajat, chobezard, aqarqarha, amba haldi, etc., and a few compound formulations which has very good antiallergic as well as possess good immunity boosting properties, for e.g., tiryaq-e-wabai, arq-e-ajeeb, Khameera marwareed, khameera abresham sheera unnab wala, habbe nazla, khameera marwareed khaas, habbe zahar mohra, khameera abresham hakeem arshad wala, etc. Many herbal formulations are effective to utilize in this pandemic for enhancing the immunity and increase the ability to fight against various diseases. Herbal formulations possess several biochemical compounds such as alkaloids, phenol, flavonoids, saponins, etc., which exhibits various pharmacological activities ranging from anti-oxidant, antibacterial, anti-inflammatory, antiviral to immune-stimulatory activities. Hence, they can enhance or boost the immunity of an individual which ultimately provide some cure or help in the symptomatic management of COVID-19.

\section{Immunomodulation}

Immunomodulations means that one can modulate immunity using various substances either of natural or synthetic origin. Certain medicinal plants promote positive health and maintain organic resistance against infection by re-establishing body equilibrium and conditioning the body tissues.

\section{Combat COVID-19 viral infection}

Novel coronavirus COVID-19 pandemic become an enormous catastrophe presenting devastating effects on entire world. It created havoc on population and killed several human beings worldwide; still the situation is not getting under control. Consequently, it makes to impose complete lockdown in different countries around the globe. Since decades, vaccination has been the only means to treat the viral infections. Though, the vaccination for COVID-19 has been developed, and reaching each and every individual is a difficult task, owing to which the scenario is worsening. Central drugs standard control organization (CDSCO) has granted two vaccines for emergency use authorization in India, i.e., Covishield ${ }^{\circledR}$ (Astra Zeneca's vaccine manufactured by Serum Institute of India) and Covaxin ${ }^{\circledR}$ (manufactured by Bharat Biotech Limited). Covishield ${ }^{\circledR}$ vaccine is a viral vector-based technology which was also used to manufacture Ebola vaccine. Covaxin ${ }^{\circledR}$ vaccine wholevirion inactivated coronavirus vaccine which was earlier used to manufacture vaccines like influenza, rabies and hepatitis-A. (Internet source, accessed on 19.04.2021). As of April 2021 vaccination doses in India are given in 123 million people and fully vaccinated 16.2 million and \% of population fully vaccinated are $1.2 \%$. (Website source, accessed on 19.04.2021). The present health crises to the people at large and their responsibility on scientific community to look for the alternatives or techniques to develop successful viral vaccination against COVID-19 infection are strongly needed. The current situation prompts us to have healthy lifestyle, natural food products which can boost the immune functions of the body to combat the severity of viral infections. While enhancing the immune responses, they also provide resistance against various pathogenic organisms (Sarfraz et al., 2020).

\section{Medicinal plants therapeutic approaches against COVID-19}

The traditional medicines are generally a great source of novel research and their usage are known since many centuries. Many plants contain phytochemical components extracted from herb or combination of herbs that may function to yield preferred pharmacological effects (Parasuraman et al., 2014).

The traditional medicine which are effective and suitable to treat various infectious disorders, viz., Ayurveda, Siddha, Yoga, Unani, Homeopathy and Naturopathy. The traditional system of medicines use plants, animals, and mineral origin products for the treatment of wide range of diseases. Many formulations have been reported in classical text of the traditional system of medicine and still being used today. Total medicinal plants being used are more than 3000 , whereas traditional system uses around 1500 species. The Ministry of AYUSH has recently introduced the Kadha as an immunity booster and lower the tenderness caused during COVID-19 catastrophe (AYUSH Advisory 2020). Few medicinal herbs are mix together and its decoction was consume to get relieve symptoms in COVID-19 and it also build one's own immune system to cope up with the 
pandemic. The holistic approach of AYUSH systems of medicine gives focus on prevention through lifestyle modification, dietary management, prophylactic interventions for improving the immunity and simple remedies based on presentations of the symptoms.

\section{Abilities of medicinal plants against coronaviruses in human}

People all over the world in particular Asian countries like India, China and Middle Africa have been using medicinal herbs since prehistoric times (Hoareau and Dasilva, 1999). Utilizing medicinal plants for healthcare are very prevalent due to its scalability, cheap and affordable than modern medicine. These medicinal plants contain a wide range of phytochemicals, including alkaloids, terpenoids, phenolic compounds, tannins, glycosides, lignins, coumarins, flavonoids, steroids, and many have been shown to be effective against a variety of infections and pathogenic microorganisms. Medicinal plants are emerged with diverse phytochemicals (Table 1), such as alkaloids, terpenoids, flavonoids, phenolic acids, tannins, lignins, coumarins, stilbenes, etc. Some vital phytoconstiuents structure are shown in Figure 2 which have been reported to potential against infections caused by pathogenic microorganisms (McCutcheon et al., 1995; Semple et al., 1998).<smiles>COc1ccc(C2CC(=O)c3c(O)cc(OC4CC(O)C(O)C(O)C(O)C4OC4OC(C)C(O)C(O)C4O)cc3O2)cc1O</smiles>

Hesperidin

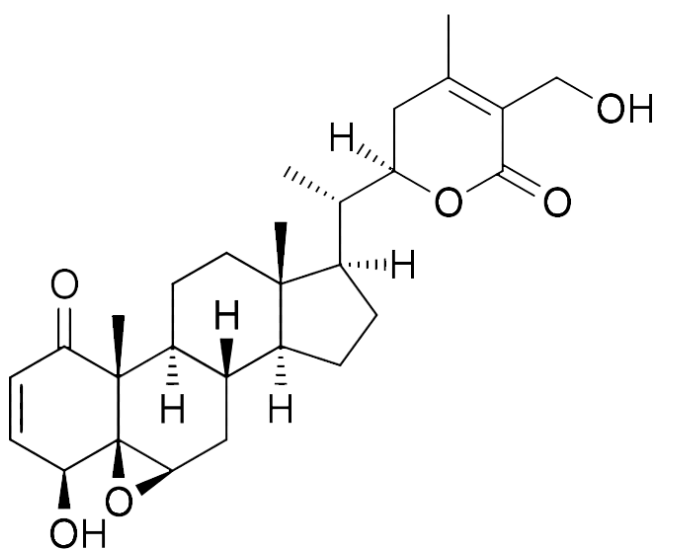

Withanferin A

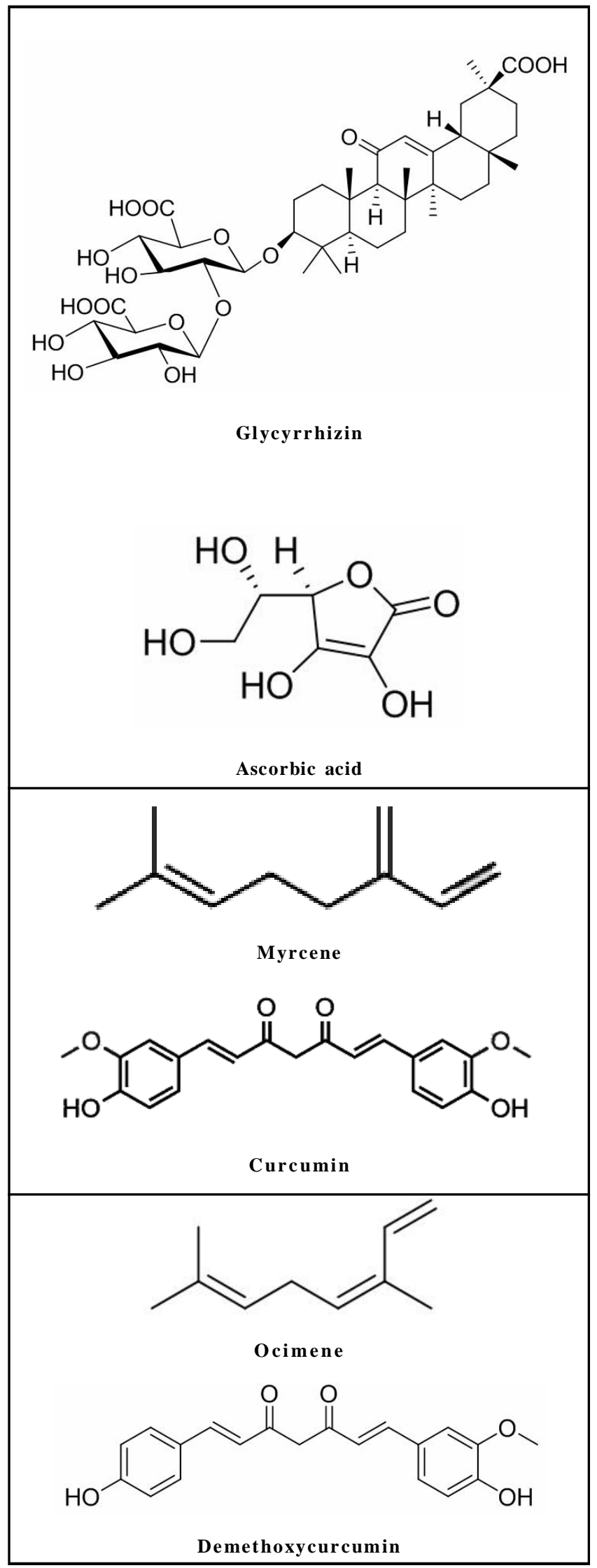




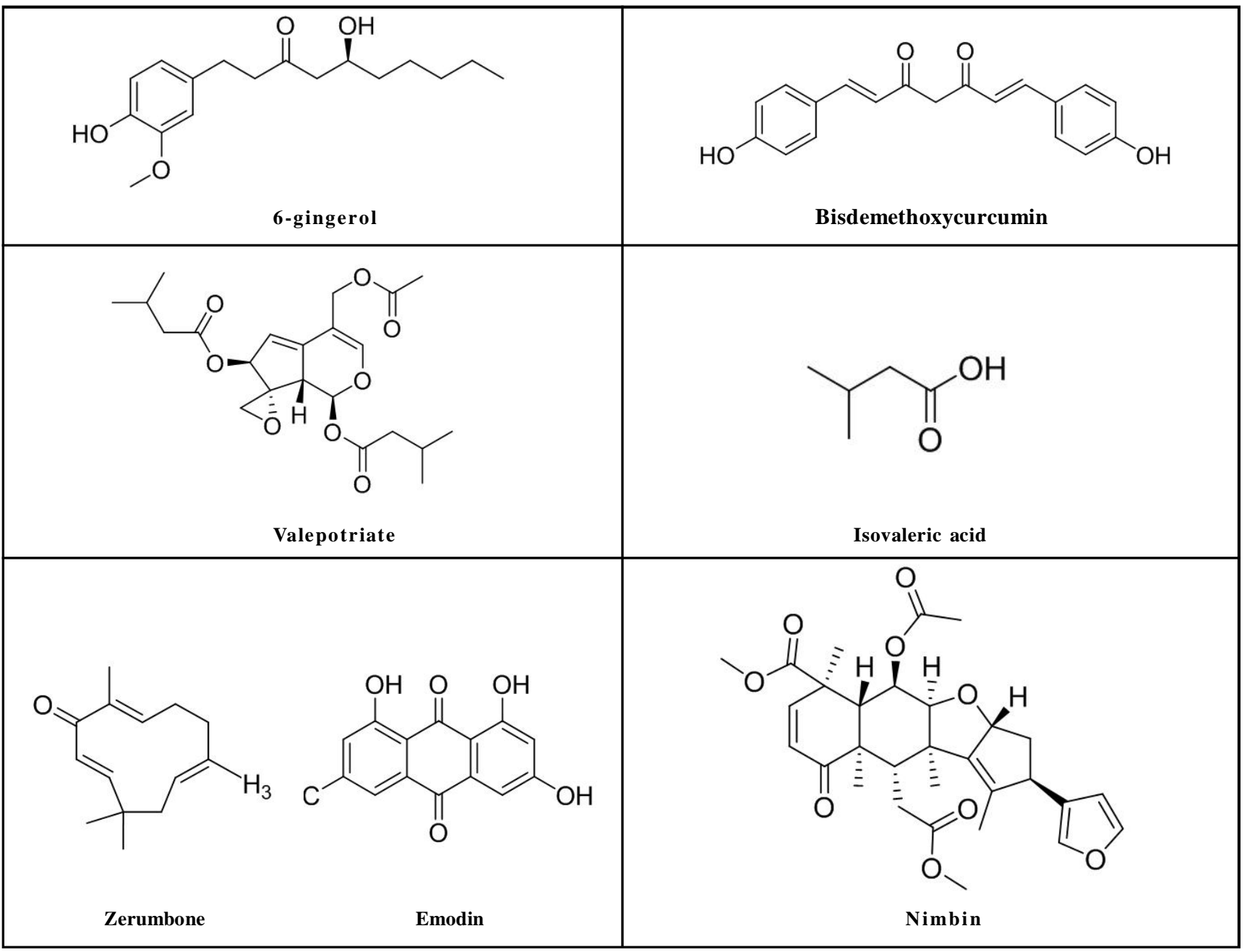

Figure 2: Structures of phytochemical compounds present in few roots and rhizomes.

Table 1: Roots and rhizomes with immunomodulatory effects

\begin{tabular}{|c|c|c|c|c|c|}
\hline $\begin{array}{l}\text { Botanical } \\
\text { name }\end{array}$ & $\begin{array}{l}\text { Common or } \\
\text { regional } \\
\text { names }\end{array}$ & Phytoconstituents & Therapeutic actions & Properties & References \\
\hline $\begin{array}{l}\text { Curcuma } \\
\text { amada Roxb. } \\
\text { (rhizhome) }\end{array}$ & $\begin{array}{l}\text { Unani name: } \\
\text { Aambahaldi, } \\
\text { English: Mango } \\
\text { ginger }\end{array}$ & $\begin{array}{l}\text { Phenolic acids, volatile } \\
\text { oils, curcuminoids and } \\
\text { terpenoids like difuro } \\
\text { cumenonol, amadannulen, } \\
\text { myrcene, ocimene }\end{array}$ & $\begin{array}{l}\text { Alcoholic extract showed } \\
\text { significant immune-modulatory } \\
\text { effect in in vitro phagocytosis } \\
\text { activity, delayed type hypersen- } \\
\text { sitivity test and hem aggluti- } \\
\text { nation test }\end{array}$ & $\begin{array}{l}\text { Immunemodu- } \\
\text { latory effect }\end{array}$ & $\begin{array}{l}\text { (Karchuli and } \\
\text { Pradhan, 2019) }\end{array}$ \\
\hline $\begin{array}{l}\text { Anacyclus } \\
\text { pyrethrum } \\
\text { DC (root) }\end{array}$ & \begin{tabular}{l|} 
Unani name: \\
Aqarqarha; \\
English:pellitory \\
pyrethrum
\end{tabular} & $\begin{array}{l}\text { Pellitorine, anacyclin, } \\
\text { phenylethylamine, inulin, } \\
\text { polyacetylenic amides } \\
\text { and sesamin, pyrethrin } \\
\text { pyrethrin A and B }\end{array}$ & $\begin{array}{l}\text { Immunostimulant activity } \\
\text { increased two -fold upon doubling } \\
\text { the dosage of petroleum ether } \\
\text { extract of roots administered. } \\
\text { While a significant }(p<0.05) \\
\text { improvement was observed in } \\
\text { the humoral component, a highly } \\
\text { significant ( } p<0.01) \text { effect was } \\
\text { observed in the cellular compo- } \\
\text { nents of the immunity evaluated. } \\
\text { The result forms a basis for } \\
\text { A. pyrethrum as an adaptogen and } \\
\text { immunomodulator in Ayurvedic } \\
\text { system of medicine. }\end{array}$ & $\begin{array}{l}\text { Immunomodulatory } \\
\text { properties, } \\
\text { antinociceptive, } \\
\text { antiinflammatory } \\
\text { and antioxidant } \\
\text { activities }\end{array}$ & $\begin{array}{l}\text { (Sharma et al., } \\
2010 \text { ) }\end{array}$ \\
\hline
\end{tabular}




\begin{tabular}{|c|c|c|c|c|c|}
\hline $\begin{array}{l}\text { Zingiber } \\
\text { officinale } \\
\text { (Rhizhome) }\end{array}$ & $\begin{array}{l}\text { Unani name: } \\
\text { Zanjabeel; } \\
\text { English: Ginger }\end{array}$ & 6 -gingerol & $\begin{array}{l}\text { Ginger essential oil recovered the } \\
\text { humoral immune response in } \\
\text { immunosuppressed mice. It has } \\
\text { high binding affinity at R7Y } \\
\text { COVID-19 activated sites, the } \\
\text { main protease essential for } \\
\text { replication and reproduction of } \\
\text { SARS Cov-2. Possesses excellent } \\
\text { druglikeliness parameters with } \\
\text { zero violations. The rhizome } \\
\text { aqueous extract showed remar- } \\
\text { kably decline in the number of } \\
\text { CD14 monocyte count with } \\
\text { exposure of HBsAg and NDV as } \\
\text { compared to control group. It } \\
\text { showed anti-inflammatory as well } \\
\text { as antiviral activity. }\end{array}$ & $\begin{array}{l}\text { Anti-inflammatory } \\
\text { as well as antiviral } \\
\text { activity }\end{array}$ & $\begin{array}{l}\text { (Carrasco et al., } \\
2009 \text {; } \\
\text { Rathinavel et al., } \\
\text { 2020; } \\
\text { Gupta and } \\
\text { Chaphalkar, } \\
\text { 2015) }\end{array}$ \\
\hline $\begin{array}{l}\text { Valeriana } \\
\text { wallichii } \\
\text { DC (root) }\end{array}$ & $\begin{array}{l}\text { Unani name: } \\
\text {-Tagar; English - } \\
\text { Indian valerian }\end{array}$ & $\begin{array}{l}\text { Valepotriates, } \\
\text { isovalerinic acid and } \\
\text { hesperidin, etc. }\end{array}$ & $\begin{array}{l}\text { The animals supplemented with } \\
\text { the aqueous root extract of } \\
V \text {. wallichii were found to adapt } \\
\text { much faster as indicated by the } \\
\text { improved malondialdehyde } \\
\text { (MDA) and lactate dehydrogenase } \\
\text { (LDH) levels as well as reduced } \\
\text { superoxide dismutase (SOD) and } \\
\text { catalase (CAT) levels in compari- } \\
\text { son to control. The study indica- } \\
\text { ted that aqueous root extract of } \\
V \text {. wallichii had adaptogenic } \\
\text { activity as assessed by C-H-R } \\
\text { animal model. Its extract was also } \\
\text { found to be more safe and effec- } \\
\text { tive than alprazolam drug in } \\
\text { alleviating the immunosuppres- } \\
\text { sion induced in restraint stress } \\
\text { exposed rats. }\end{array}$ & $\begin{array}{l}\text { Adaptogenic } \\
\text { activity, } \\
\text { immunemodulatory } \\
\text { effect. }\end{array}$ & $\begin{array}{l}\text { (Sharma et al., } \\
\text { 2012; Ibrahim } \\
\text { et al., 2016) }\end{array}$ \\
\hline $\begin{array}{l}\text { Withania } \\
\text { somnifera } \\
\text { Dunal (Root) }\end{array}$ & $\begin{array}{l}\text { Unani name - } \\
\text { Asgand; } \\
\text { English- } \\
\text { Asarbacca }\end{array}$ & Withaferin A & $\begin{array}{l}\text { The immunornodulatory, anti- } \\
\text { inflammatory, antistress, } \\
\text { cognition facilitating and anti- } \\
\text { aging effects produced by active } \\
\text { principles of } W \text {. soomni fera in } \\
\text { experimental animals, and in } \\
\text { clinical situations. A protective } \\
\text { effect in cyclophosphamide- } \\
\text { induced myelosuppression was } \\
\text { observed in animals treated with } \\
\text { WST and WS2, a significant } \\
\text { increase in white blood cell } \\
\text { counts and platelet counts was } \\
\text { revealed. Cyclophosphamide } \\
\text {-induced immunosuppression was } \\
\text { counteracted by treatment with } \\
\text { WS2, revealing significant increase } \\
\text { in hemolytic antibody responses } \\
\text { and hemagglutinating antibody } \\
\text { responses towards sheep red blood } \\
\text { cells. The W. Somnifera extract } \\
\text { inhibited delayed type hypersen- } \\
\text { tivity reaction in mice model } \\
\text { (Mantoux test). Administration of } \\
W . \text { somni fera extract also showed } \\
\text { an enhancement in phagocytic } \\
\text { activity of peritoneal macro- } \\
\text { phages (76.5 pigmented cells/ } \\
\text { 200) upon compared to control }\end{array}$ & $\begin{array}{l}\text { Antistress, } \\
\text { immunornodulatory, } \\
\text { cognition- } \\
\text { facilitating, } \\
\text { anti-inflammatory } \\
\text { and antiageing } \\
\text { effects } \\
\\
\\
\end{array}$ & $\begin{array}{l}\text { (Bhattacharya } \\
\text { et al., 1997; } \\
\text { Agarwal et al., } \\
\text { 1999; Davis } \\
\text { and Kuttan, 2000) }\end{array}$ \\
\hline
\end{tabular}




\begin{tabular}{|c|c|c|c|c|c|}
\hline & & & $\begin{array}{l}\text { (31.5/200 cells) in mice. The } \\
\text { results yield the immunomodu- } \\
\text { latory activity of } W \text {. somnifera } \\
\text { extract, which is a known immu- } \\
\text { nomodulator in the indigenous } \\
\text { system of medicine. }\end{array}$ & & \\
\hline $\begin{array}{l}\text { Glycyrrhiza } \\
\text { glabra } \\
\text { Linn (root) }\end{array}$ & $\begin{array}{l}\text { Unani name: } \\
\text { Aslus-soos; } \\
\text { English Liqourice } \\
\text { root }\end{array}$ & $\begin{array}{l}\text { Glycyrrhizin, } \\
\text { liquiritigenin, glabridin, } \\
\text { liquiritin and isoliqui- } \\
\text { ritinglycyrrhetic acid, }\end{array}$ & $\begin{array}{l}\text { In vivo phagocytosis (carbon } \\
\text { clearance method -CCM), } \\
\text { determination of cellular immune } \\
\text { response, plaque forming cell and } \\
\text { haemagglutination antibody titre } \\
\text { assay using sheep red blood cells. } \\
\text { In cellular immune response study, } \\
\text { an enhancement in foot pad thick- } \\
\text { ness was recorded when compared } \\
\text { to control group. The study } \\
\text { showed the immunemodulatory } \\
\text { activity of aqueous root extract of } \\
\text { G. glabra L. at the dose } 1.5 \text { g/kg } \\
\text { BW. G. glabra in combination } \\
\text { with zinc has shown potentiation } \\
\text { of immunemodulatory activity in } \\
\text { all aspects of the study. Glycirrhiza } \\
\text { glabra extracts showed effective } \\
\text { against HIV, herpes viruses, RSV, } \\
\text { and severe acute respiratory } \\
\text { syndrome-related coronavirus. } \\
\text { Possess powerful antiviral pro- } \\
\text { perties and counter balance the } \\
\text { activeness of COVID-19 and may } \\
\text { use as an antiviral drug. Antiviral } \\
\text { potential application as wound } \\
\text { dressing materials, musk, gloves } \\
\text { and against skin infection by } \\
\text { electrospinning. licorice processed } \\
\text { with PVA solution to form anti- } \\
\text { viral nano-membrane. }\end{array}$ & $\begin{array}{l}\text { Immune response } \\
\text { and antiviral }\end{array}$ & $\begin{array}{l}\text { (Mazumder et al., } \\
2012 ; \text { Chowdhury } \\
\text { et al., 2020) }\end{array}$ \\
\hline $\begin{array}{l}\text { Chlorophytum } \\
\text { borivilianum }\end{array}$ & $\begin{array}{l}\text { Unani name: } \\
\text { Musli safed; } \\
\text { English- Raddish }\end{array}$ & $\begin{array}{l}\text { Ethanolic extract of } \\
\text { the roots }\end{array}$ & $\begin{array}{l}\text { The root ethanolic extract and its } \\
\text { sapogenin were evaluated for } \\
\text { immunomodulatory activity. Effect } \\
\text { of azathioprine-induced myelo- } \\
\text { suppresion and administration of } \\
\text { extracts on hematological and } \\
\text { serological parameters was assayed. } \\
\text { Administration of extracts greatly } \\
\text { improved survival against } \\
\text { Candida albicans infection. } \\
\text { There had been an increase in } \\
\text { delayed-type hypersensitivity } \\
\text { response, \% neutrophil adhesion } \\
\text { and in vivo phagocytosis by } \\
\text { carbon clearance method (CCM) } \\
\text { was observed after treatment } \\
\text { with extracts. Root ethanolic } \\
\text { extract shown immunostimulant } \\
\text { activity was more pronounced as } \\
\text { compared to sapogenins. }\end{array}$ & $\begin{array}{l}\text { Immune- } \\
\text { modulatory } \\
\text { activity }\end{array}$ & $\begin{array}{l}\text { (Thakur et al., } \\
\text { 2007) }\end{array}$ \\
\hline $\begin{array}{l}\text { Curcuma } \\
\text { longa } \\
\text { (Rhizome) }\end{array}$ & $\begin{array}{l}\text { Unani name: } \\
\text { Chobzard; } \\
\text { English- } \\
\text { Turmeric }\end{array}$ & $\begin{array}{l}\text { Curcumin, } \\
\text { Demethoxycurcumin, }\end{array}$ & $\begin{array}{l}\text { C. longa was analysed forimmune- } \\
\text { modulatory activity in Balb/c mice. } \\
\text { Curcuminincreased the circulating } \\
\text { antibody titre (512) against } \\
\text { sheep red blood cells (SRBC). } \\
\text { Curcumin administration increased } \\
\text { the plaque forming cells in the } \\
\text { spleen and the maximum number }\end{array}$ & $\begin{array}{l}\text { Best potential to } \\
\text { act as COVID-19 } \\
\text { Mpro inhibitors. } \\
\text { Treatment and } \\
\text { prophylaxis }\end{array}$ & $\begin{array}{l}\text { (Antony et al., } \\
\text { 1999; Sengupta } \\
\text { et al., 2011) }\end{array}$ \\
\hline
\end{tabular}




\begin{tabular}{|c|c|c|c|c|c|}
\hline & & & $\begin{array}{l}\text { of PFC was observed on the } 6 \text { th } \\
\text { day }(1,130 \text { PFC/106 spleen cells) } \\
\text { after immunization with SRBC. } \\
\text { The bone marrow cellularity (16.9 } \\
\times 106 \text { cells/femur) and } \gamma \text {-esterase } \\
\text { positive cells }(1,622 / 4000 \text { cells) } \\
\text { are also enhanced with curcumin } \\
\text { administration. A significant } \\
\text { increase in macrophage phagocytic } \\
\text { activity was observed into the } \\
\text { curcumin treated animals ( } p<0.001) \text {. } \\
\text { The results indicated immune- } \\
\text { stimulatory activity of curcumin. } \\
\text { The aqueous extract of } C \text {. longa } \\
\text { offered significant protection from } \\
\text { these damaging actions of CCl4 } \\
\text { on the non-specific host response } \\
\text { in the peritoneal macrophages of } \\
\text { CCl4 intoxicated mice. C. longa } \\
\text { shown to have immunotherapeutic } \\
\text { properties along with its ability to } \\
\text { ameliorate hepatotoxicity. }\end{array}$ & & \\
\hline $\begin{array}{l}\text { Zingiber- } \\
\text { zerumbet (L.) } \\
\text { (rhizhome) }\end{array}$ & $\begin{array}{l}\text { (Unani name: } \\
\text { zarnabad/ } \\
\text { narkachoor }\end{array}$ & Zerumbone & $\begin{array}{l}\text { The aqueous extract of Z.zerumbet } \\
\text { (CC-ZWE) in protecting the lungs } \\
\text { by inhibiting the release of infla- } \\
\text { mmatory mediators during short- } \\
\text { term treatment, and modulating } \\
\text { cytokine gene expressions during } \\
\text { long-term treatment. The ZZ-CWE } \\
\text { have beneficial effects for the } \\
\text { treatment of asthmatic patients } \\
\text { through its capabilities to inhibit } \\
\text { the synthesis of LTC4 and through } \\
\text { the immunomodulation of Th1/ } \\
\text { Th2 cytokine production. The } \\
\text { immune-modulatory effects of } \\
\text { zerumbone isolated from } \\
\text { Z.zerumbet investigated by } \\
\text { evaluating the effects towards the } \\
\text { lymphocytes proliferation (mice } \\
\text { thymocytes, mice splenocytes and } \\
\text { human peripheral blood mono- } \\
\text { nuclear cells, PBMC), cell cycle } \\
\text { progression and cytokine (inter- } \\
\text { leukin } 2 \text { and } 12 \text { ) induction. } \\
\text { Zerumbone produces as immuno } \\
\text {-modulatory agent which can react } \\
\text { toward the immune cell cytokine } \\
\text { production in dosage dependent } \\
\text { pattern. }\end{array}$ & $\begin{array}{l}\text { Immuno- } \\
\text { modulatory } \\
\text { effects }\end{array}$ & $\begin{array}{l}\text { (Chaung et al., } \\
\text { 2008; Keong } \\
\text { et al., 2010) }\end{array}$ \\
\hline $\begin{array}{l}\text { Allium } \\
\text { sativum } \\
\text { Linn. (Bulb) }\end{array}$ & $\begin{array}{l}\text { Unani name: } \\
\text { Seer, } \\
\text { English, Garlic) }\end{array}$ & $\begin{array}{l}\text { Essential oil, } \\
\text { Allyldisulfide, } \\
\text { Allyltrisulfide }\end{array}$ & $\begin{array}{l}\text { The changes in garlic during ageing } \\
\text { examined by protein quantitation } \\
\text { and gel electrophoresis. Purifi- } \\
\text { cation and identification of the } \\
\text { immune-modulatory proteins } \\
\text { have been achieved by Q-sepharose } \\
\text { chromatography and mitogenic } \\
\text { activity. Only two major proteins } \\
\text { (12-14 kDa range by SDS-PAGE) } \\
\text { were observed in AGE. The puri- } \\
\text { fied protein components QA-1, } \\
\text { QA-2, and QA-3 display Immuno- } \\
\text { modulatory and mannose-binding } \\
\text { activity; QA-2 shows the highest } \\
\text { mitogenic activity. The identity of }\end{array}$ & $\begin{array}{l}\text { Immuno- } \\
\text { modulatory effect } \\
\text { and Immuno- } \\
\text { stimulant }\end{array}$ & $\begin{array}{l}\text { (Chandrashekar } \\
\text { and Venkatesh, } \\
2009 ; \text { Thuyet } \\
\text { et al., 2020) }\end{array}$ \\
\hline
\end{tabular}




\begin{tabular}{|c|c|c|c|c|c|}
\hline & & & $\begin{array}{l}\text { QA-2 and QA-1 proteins with the } \\
\text { garlic lectins ASA I and ASA II, } \\
\text { respectively, had confirmed by } \\
\text { hemagglutination analysis. QA-3 } \\
\text { exhibits mitogenic activity, but no } \\
\text { hemagglutination activity. The } \\
\text { immune-modulatory activity of } \\
\text { AGE contributed by immune- } \\
\text { modulatory proteins. The major } \\
\text { immune-modulatory proteins } \\
\text { identified as the well-known } \\
\text { garlic lectins. A remedy for various } \\
\text { diseases and viral infections. } \\
\text { Possesses antiviral activity against } \\
\text { influenza A and B, HIV, HSV-1, } \\
\text { viral pneumonia, and common cold } \\
\text { Essential or volatile oil as crucial } \\
\text { natural antiviral source to combat } \\
\text { with coronavirus infection. }\end{array}$ & & \\
\hline Rheum emodi & $\begin{array}{l}\text { Unani name: } \\
\text { Revand }\end{array}$ & Emodin & $\begin{array}{l}\text { Emodincompound reported to } \\
\text { block the binding of SARS-Cov } \\
\text { protein to ACE2. A potential } \\
\text { lead therapeutic against the } \\
\text { management or treatment of } \\
\text { COVID-19. }\end{array}$ & $\begin{array}{l}\text { Antiviral } \\
\text { properties }\end{array}$ & (Ho et al., 2007) \\
\hline $\begin{array}{l}\text { Azadirachta } \\
\text { indica }\end{array}$ & $\begin{array}{l}\text { Unani name: } \\
\text { Neem }\end{array}$ & $\begin{array}{l}\text { Neem leaf extract contains } \\
\text { nimbin, nimbanene, } \\
\text { 6-desacetylnimbinene, } \\
\text { nimbandiol, nimbolide, } \\
\text { ascorbic acid }\end{array}$ & $\begin{array}{l}\text { Boost the immune system by } \\
\text { triggering your cell-mediated } \\
\text { immune system into overdrive. } \\
\text { Boosts the body macrophage } \\
\text { response, which also stimulates } \\
\text { the lymphocytic system and boosts } \\
\text { the production of white blood cells } \\
\text { (WBC). }\end{array}$ & $\begin{array}{l}\text { Potent antiviral } \\
\text { agent, immune } \\
\text { stimulant }\end{array}$ & $\begin{array}{l}\text { (Kwawukume } \\
\text { et al., 2013) }\end{array}$ \\
\hline
\end{tabular}

\section{Conclusion}

Phytochemical evidence suggests that the active constituents present in medicinal plants have pharmacological properties against some bacteria and viruses, as well as immune-stimulatory effects, implying that they could be used to treat COVID-19 disease. Phytochemicals benefit and helps in rejuvenate the lost health and build up the immune system of human body to fight against the viruses and other foreign bodies. Over the past one year, the sudden outbreak of COVID-19 urge to identify the root cause of infection and explain the major global concern. Through, the use of potent medicinal plants and various herbal formulations, it is necessary to identify and conduct extensive research in order to develop a specific drug that can combat the novel coronavirus and, thus help humanity live a peaceful life.

\section{Acknowledgements}

The authors are thankful to the Director General, CCRUM, New Delhi, and also Director, NRIUMSD, Hyderabad for providing necessary facilities.

\section{Conflict of interest}

The authors declare that there are no conflicts of interest relevant to this article.

\section{References}

Agarwal, R.; Diwanay, S.; Patki, P. and Patwardhan, B. (1999). Studies on immunomodulatory activity of Withania somnifera (Ashwagandha) extracts in experimental immune inflammation. Journal of Ethnopharmacology, 67(1):27-35.
Antony, S.; Kuttan, R. and Kuttan, G. (1999). Immunomodulatory activity of curcumin. Immunological investigations, 28(5-6):291-303.

AYUSH Advisory (2020). https://www.ayush.gov.in/docs/125.pdf

Bhattacharya, S.K.; Satyan, K.S. and Ghosal, S. (1997). Antioxidant activity of glycowithanolides from Withania somnifera. Indian Journal of Experimental Biology, 35:236-239.

Carrasco, F.R.; Schmidt, G.; Romero, A.L.; Sartoretto, J.L.; Caparroz Assef, S.M.; Bersani Amado, C.A. and Cuman, R.K.N. (2009). Immunomodulatory activity of Zingiber officinale Roscoe, Salvia officinalis L. and Syzygium aromaticum L. essential oils: Evidence for humor and cell mediated responses. Journal of Pharmacy and Pharmacology, 61(7):961-967.doi: 10.1211/jpp/61.07.0017.

Chandrashekar, P.M. and Venkatesh, Y.P. (2009). Identification of the protein components displaying immunomodulatory activity in aged garlic extract. Journal of Ethnopharmacology, 124(3):384-390.

Chaung, H.C.; Ho, C.T. and Huang, T.C. (2008). Anti-hypersensitive and antiinflammatory activities of water extract of Zingiber zerumbet (L.) Smith. Food and Agricultural Immunology, 19(2):117-129

Chowdhury, M.A.; Shahid, M.A. and Kashem, M.A. (2020). Scope of natural plant extract to deactivate COVID-19. Eur. PMC. https://doi.org/ 10.21203/rs.3.rs-19240/v1.

Davis, L. and Kuttan, G. (2000). Immunomodulatory activity of Withania somnifera. Journal of Ethnopharmacology, 71(1-2):193-200.

Dong, L., Hu, S. and Gao, J. (2020). Discovering drugs to treat coronavirus disease 2019 (COVID-19). Drug Discoveries and Therapeutics, 14(1): 58-60. https://doi.org/10.5582/ddt.2020.01012. 
Gorbalenya, A.E.; Baker, S.C.; Baric, R.S.; de Groot, R.J ; Drosten, C.; Gulyaeva, A.A.; Haagmans, B.L.; Lauber, C.; Leontovich, A.M.; Neuman, B.W.; Penzar D.; Perlman, S.; Poon, L.L.M.; Samborskiy, D.V.; Sidorov, I.A.; Sola, I. and Ziebuhr, J. (2020). The species severe acute respiratory syndromerelated coronavirus: classifying 2019-nCoV and naming it SARSCoV-2. Nature Microbiology, 5:536-544. https://doi.org/10.1038/ s4 1564- 020-0695-z

Gupta, A. and Chaphalkar, S.R. (2015). Immunopharmacological activity of Zingiber officinale on human peripheral blood mononuclear cells. Asian Journal of Medical and Pharmaceutical Researches, 5(2):13-17.

Ho, T.W.; Wu, S.L.; Chen, J.C.; Li, C.C. and Hsiang, C.Y. (2007). Emodin blocks the SARS coronavirus spike protein and angiotensin-converting enzyme 2 interaction. Antiviral Research, 74:92-101.

Hoareau, L. and DaSilva, E.J. (1999). Medicinal plants: a re-emerging health aid. Electronic Journal of Biotechnology, 2:56.

Huang, C.; Wang, Y.; Li, X.; Ren, L.; Zhao, J.; Hu, Y.; Zhang, L.; Fan, G.; Xu, J.; Gu X.; Cheng, Z.; Yu, T.; Xia, J.; Wei, Y.; Wu, W.; Xie, X.; Yin, W.; Li, H.; Liu, M.; Xiao, Y.; Gao, H.; Guo, L.; Xie, J.; Wang, G.; Jiang, R.; Gao, Z.; Jin, Q. Wang, J. and Cao, B.(2020). Clinical features of patients infected with 2019 novel coronavirus in Wuhan, China. Lancet, 395 (102 23):497-506.https://doi.org/10.1016/S0140-6736(20)3018 3-5.

Ibrahim, N.A.; Ibrahim, S.S.; Mannaa, F.A.; Abdel-Wahhab, K.G. and Ali, M.A (2016). An extra-alleviative effect of valerian extract as compared to that of alprazolam drug against immunomodulation caused by chronic restraint stress in rats. The Egyptian Journal of Experimental Biology (Zoology), 12(1):67-72.

Karchuli, M.S. and Pradhan, D. (2019). Curcuma amada roxb. Rhizome extract modulates cellular and humoral immune system. Pharmacologyonline, 3:947-952.

Keong, Y.S.; Alitheen, N.B.; Mustafa, S.; Aziz, S.A.; Rahman, M.A. and Ali, A.M (2010). Immunomodulatory effects of zerumbone isolated from roots of Zingiber zerumbet. Pakistan Journal of Pharmaceutical Sciences, 23(1):75-82.

Khan S.A. and Al-Balushi K. (2021). Combating COVID-19: The role of drug repurposing and medicinal plants. Journal of Infection and Public Health, 14(4):495-503.

Kwawukume, A.A.; Aninga, K.G.; Awunib, J.A.; Otsyinac, H. and Awumbila, B. (2013). The effects of Azadirachta indica (neem) leaf extract on white blood cell count and the immune response of chickens vaccinated with Newcastle disease vaccine. Int. J. Current Science, 7:23-31.
Mazumder, P.M.; Pattnayak, S.; Parvani, H.; Sasmal, D. and Rathinavelusamy, P. (2012). Evaluation of immunomodulatory activity of Glycyrhiza glabra L. roots in combination with zing. Asian Pacific Journal of Tropical Biomedicine, 2(1):S15-S20.

Mc Cutcheon, A.R.; Roberts, T.E.; Gibbons, E.; Ellis, S.M. and Babiuk, L.A. (1995) Antiviral screening of British Columbian medicinal plants. Journal of Ethnopharmacology, 49:101.

Parasuraman, S.; Thing, G.S. and Dhanaraj, S.A. (2014). Polyherbal formulation: Concept of Ayurveda. Pharmacognosy Review, 8(16): 73.

Rathinavel, T.; Palanisamy, M.; Palanisamy, S.; Subramanian, A. and Thangaswamy, S. (2020). Phytochemical 6-gingerol: A promising drug of choice for COVID-19. International Journal of Advanced Science and Engineering, 6(4):1482-1489.

Sarfraz, I.; Rasul, A.; Hussain, G.; Adem, S. and Ali, M. (2020). Natural immune boosters as first-line armours to combat viral infection-COVID19: myth or science? Preprints 2020, 2020030427 (doi: 10.20944/ preprints202003.0427.v1).

Semple, S.J.; Reynolds, G.D.; leary, M.C. and Flower, R.L.P. (1998). Screening of Australian medicinal plants for antiviral activity. Journal of Ethnopharmacology, 60:163

Sengupta, M.; Sharma, G.D. and Chakraborty, B. (2011). Hepatoprotective and immunomodulatory properties of aqueous extract of Curcuma longa in carbontetra chloride intoxicated Swiss albino mice. Asian Pacific Journal of Tropical Biomedicine, 1(3):193-199.

Sharma, P.; Kirar, V.; Meena, D.K.; Suryakumar, G. and Misra, K. (2012). Adaptogenic activity of Valerianawallichii using cold, hypoxia and restraint multiple stress animal model. Biomedicine and Aging Pathology, 2(4):198-205.

Sharma, V.; Thakur, M.; Chauhan, N.S. and Dixit, V.K. (2010). Immunomodulatory activity of petroleum ether extract of Anacyclus pyrethrum. Pharmaceutical Biology, 48(11):1247-1254.

Srivastava, A.K., Kumar, A. and Misra, N. (2020). On the inhibition of COVID19 protease by Indian herbal plants: An in silico investigation. ArXiv preprint arXiv: 2004.03411.

Thakur, M.; Bhargava, S. and Dixit, V.K. (2007). Immunomodulatory activity of Chlorophytum borivilianum Sant. F. Evidence-Based Complementary and Alternative medicine, 4(4):419-423.

Thuy, B.T.P.; My, T.T.A.; Hai, N.T.T.; Hieu, L.T.; Hoa, T.T.; Loan, T.P.H.; Triet, N.T.; Anh, T.T.V.; Quy, P.T.; Tat, P.V. and Hue, N.V. (2020). Investigation into SARS-CoV-2 resistance of compounds in garlic essential oil. ACS Omega, 5:8312-8320. 